Meta

Journal des traducteurs

Translators' Journal

\title{
Hermeneutics in Interpreting Studies Research: Legacy of the Past into the Future
}

\section{Duygu Çurum Duman}

Volume 60, numéro 2, août 2015

$60^{\mathrm{e}}$ anniversaire. Les horizons de la traduction : retour vers le futur $60^{\text {th }}$ Anniversary. Translation's Horizons: Back to the Future

60mo aniversario. Los horizontes de la traducción: regreso al futuro

URI : https://id.erudit.org/iderudit/1032878ar

DOI : https://doi.org/10.7202/1032878ar

Aller au sommaire du numéro

Éditeur(s)

Les Presses de l’Université de Montréal

ISSN

0026-0452 (imprimé)

1492-1421 (numérique)

Découvrir la revue

Citer ce document

Duman, D. Ç. (2015). Hermeneutics in Interpreting Studies Research: Legacy of the Past into the Future. Meta, 60(2), 327-327. https://doi.org/10.7202/1032878ar d'utilisation que vous pouvez consulter en ligne. 


\title{
Hermeneutics in Interpreting Studies Research: Legacy of the Past into the Future
}

\author{
Duygu Çurum Duman \\ Yildiz Technical University, Istanbul, Turkey \\ duygucurum@gmail.com; dduman@yildiz.edu.tr
}

Since Friedrich Schleiermacher introduced his theory of interpretation for translation in the late 1700s, the role and importance of hermeneutics in translation has been a point of interest among mainly German-speaking scholars and researchers. Along with theirs, the legacy of Hans-Georg Gadamer and Paul Ricoeur in hermeneutics has reflected upon Translation Studies as an approach rather than a method in its own right. In recent years, this hermeneutical approach in Translation Studies has started to gain a new ground mainly owing to the activities of Fritz Paepcke and Radegundis Stolze in Germany. However, Interpreting Studies is more or less a bare ground with respect to hermeneutic thought, except for the recent $\mathrm{PhD}$ thesis published as a book by Miriam Leibbrand. In this respect, Interpreting Studies is yet to explore the legacy of the past in the future.

In this study, this new and flourishing approach in Interpreting Studies shall be discussed in comparison with its relatively deep-rooted development in Translation Studies. The role of hermeneutics as an approach while studying interpreting and as a research methodology among others shall be dwelt upon and the results of a prior quantitative study conducted for identifying the array of methodologies used within the field of Interpreting Studies will form the basis of the discussion. The importance of shedding a methodological light upon this issue lies in the fact that the tension between naturalistic and Geisteswissenschaften-based understanding of social sciences has been argued upon widely, with few voices from the methodological point of view both in Translation and Interpreting Studies. Therefore, the study is thought to enlighten a long-neglected issue in Interpreting Studies.

Duygu Çurum Duman is research assistant at the Department of Western Languages and Literatures, Program of Translation and Interpreting at Yildiz Technical University, Istanbul, Turkey. She has received her B.A. degree in Translation and Interpreting in English-TurkishFrench at Hacettepe University, Ankara, Turkey. Following her M.A. thesis entitled the Effect of the Imagery Mnemonic Method of Loci in Consecutive Interpreter Training (2010), supervised by Prof. Dr. Aymil Doğan at the said university, she switched to Yildiz Technical University, where she started pursuing a PhD degree on Hermeneutics and Interpreting Studies. Her research interests are conference and community interpreting, research methodologies in Interpreting Studies and hermeneutics in social sciences. She has recently published "L'identité et ses représentations: Ethos et Pathos" in Synergie Turquie (2012). 